Research articles

\title{
Students' reflective thinking based on their levels of emotional intelligence in mathematical problem-solving
}

\author{
Dwi Priyo Utomo ${ }^{1}$, Erentrudis Junirestu ${ }^{1}$, Arif Hidayatul Khusna ${ }^{1}$
}

\begin{abstract}
Abstrak Penelitian kualitatif ini bertujuan untuk menganalisis pemikiran reflektif siswa sekolah menengah pertama dalam menyelesaikan masalah matematika berbasis kecerdasan emosional. Subjek penelitian adalah empat siswa, dipilih dari 29 siswa yang mengisi kuesioner. Data dikumpulkan melalui tes dan wawancara kemudian dianalisis dengan merujuk pada empat langkah pemecahan masalah Polya yang diintegrasikan dengan indikator berpikir reflektif. Hasil penelitian ini menunjukkan bahwa siswa dengan tingkat kecerdasan emosional tinggi memenuhi semua indikator berpikir reflektif dalam pemecahan masalah. Dalam hal ini, siswa mampu memberikan reaksi pada situasi atau permasalahan yang diberikan dengan memahami secara cermat informasi yang ada, melakukan komparasi antar elemen untuk menyusun strategi, menjelaskan secara rinci langkah memecahkan masalah, melakukan kontemplasi dalam memeriksa langkah demi langkah dan memperbaiki kesalahan. Sedangkan siswa dengan tingkat kecerdasan emosional sedang kurang reflektif dalam melakukan komparasi antar elemen untuk menyusun strategi pemecahan masalah.
\end{abstract}

Kata kunci Berpikir reflektif, Pemecahan masalah, Kecerdasan emosional

\begin{abstract}
This qualitative research aims to analyze secondary students' reflective thinking in solving mathematical problems based on their emotional intelligence (EI). It involved four secondary school students selected from twenty-nine students who were given the EI questionnaire. The research instrument was a test and an interview guideline. Data analysis was referred to as Polya's four problem-solving stages integrated with the indicators of reflective thinking. The findings reveal that students with a high level of emotional intelligence can fulfill the whole indicators of reflective thinking. In this case, the students can react to a given situation or problem by carefully understanding the available information, making comparisons between elements to formulate strategies, explaining in detail the steps to solve problems, and doing contemplation in checking step by step and correcting mistakes. Meanwhile, students with mid-levels of emotional intelligence are less reflective in making comparisons between elements to formulate strategies for problem-solving.
\end{abstract}

Keywords Reflective thinking, Problem-solving, Emotional intelligence

\section{Introduction}

Reflective thinking constitutes one of the thinking skills proven to be effective in facilitating students when solving problems (Demirel, Derman \& Karagedik, 2015; Erdoğan, 2020). It hones students' accuracy and concentration in their study journey (Funny et al., 2019). However, most mathematics teachers at schools have not fostered the sharpening of this sort of reflective thinking (Rahmi, Zubainur, \& Marwan, 2020). Very rarely do teachers introduce and get their

\footnotetext{
${ }^{1}$ Universitas Muhammadiyah Malang, Jln. Bendungan Sutami No.188 Malang 65145, Indonesia, dwi_priyo@umm.ac.id
} 
students accustomed to reflective thinking in solving mathematical problems (Salido \& Dasari, 2019). Reflective thinking focuses on beliefs in deciding what to believe or do. In other words, reflective thinking is considering appropriately and carefully all alternatives before making a decision. In the decision-making process, EI can regulate emotions with intelligence; this shows that reflective thinking relates to individuals' emotional intelligence.

Emotional intelligence (EI) is perceived as one of the internal factors that potentially influence students' learning achievement in general (Paguyo-Gumangan, 2018; Seng et al., 2016) and mathematics performances in specific (Shafiee et al., 2016). Awai and Ogori (2016) explicate that EI incorporates intellectual processes that lead individuals to express their emotions aiming for raised-motivation, well-designed plan, and target orientation. Goleman has assumed that this sort of emotional competence develops via the drive of experiences and selfreflection (Mitchell-White, 2010).

Prior studies (e.g., Albayrak et al., 2018; Deringöl, 2019; Zahara, Hajidin \& Abidin, 2020) have addressed the roles of reflective thinking relating to success in mathematics. Considering the roles of reflective thinking and emotional intelligence in teaching and learning, this research was conducted to analyze students' reflective thinking in solving mathematical problems based on their level of emotional intelligence; whether students with different levels of emotional intelligence think reflectively in mathematical problem-solving. The findings are expected to enrich our understanding regarding the roles played by EI and reflective thinking in mathematics teaching and learning.

\section{Theoretical review}

\section{Reflective thinking}

Reflective thinking refers to an active process of decision-making by revisiting prior experiences - thinking of, discussing, and re-evaluating them according to specific purposes (Yildirim, 2017). In this case, it is of great importance that students are reinforced to develop their thinking skills as attempts to achieve quality improvement in mathematics instructions. Pianpeng and Koraneekij (2016) aver that reflective thinking is a process of researching and seeking interesting objects from stimuli derived from previous experiences, which lead to shifted perspectives over new ideas. By having reflective thinking skills, students will be equipped with a higher thinking level as it triggers them to review what they have formerly done and transform their understanding based on new information and experiences. Reflective thinking constitutes a process students are to be equipped with to identify and solve problems by utilizing their background knowledge and experiences (Rasyid et al., 2018). It is initiated by confusion before eventually proceeding to an investigation stage to find out an alternative solution. It triggers students to develop their strategies to solve problems by means of incorporating reflection throughout the processes.

There are several characteristics of reflective thinking: reflection as retrospective analysis, reflection as problem-solving, critical reflection on oneself, and reflection on self-esteem and success (Choy \& Oo, 2012). Rasyid et al. (2018) explain the components of reflective thinking: 1) reaction, which refers to the initial students' responses to the personal understanding of certain occurrences, situations, or problems; 2) elaboration/comparisons refers to an attempt on which students make analysis and clarification over meanings and information they believe by comparing the reaction to experiences they have faced; and 3) contemplation, which prioritizes in-depth personal understanding, such as describing, informing, considering, and reconstructing 
specific situations or problems. Accordingly, those who undergo reflection will have a clear judgment over something through their learning process.

The lack of teachers' attention to learning development in the classroom tends to get preoccupied with routine problems and negligence to personal experiences. For those reasons, students are found to have a low level of reflective thinking skills (Muin et al., 2018). Suharna et al. (2020) assert that the lack of reflective thinking skills may cause fallacies among students in solving mathematical problems at schools and may result in a deficient understanding of the given problems. Besides, it shows that students' reflective thinking skill does not earn special attention as teachers are concerned more with learning achievement than how the students get the answers to the problems. In contrast, reflective thinking is vital in learning mathematics as it constitutes a determinant factor of students' success in solving mathematical problems (Toraman et al., 2020).

\section{Mathematical problem-solving}

Problem-solving, in essence, is one activity to integrate rules and concepts formerly obtained, and it covers understanding the problems, structuring plans for the solutions, calculating, and examining (Hidayat, 2018). Problem-solving signifies an effort to find out solutions by way of planned thinking processes (Bayuningsih et al., 2017). To a broader extent, the students themselves can structure their understanding according to their experiences in an attempt to get accurate solutions for particular problems. Problem-solving also is an attempt to find solutions accurately and effectively for specific problems using a well-planned thinking process.

Mathematical problem solving is a determining stage in which students answer any questions they are challenged with. Mathematical problem solving is defined as a process of finding answers based on steps of problem-solving, starting from understanding the problems, structuring plans for the solutions, implementing the solutions, and assuring the answers/solutions (Novriani \& Surya, 2017). This sort of process offers students ample opportunities to promote and develop their thinking skills and strategies to solve any given problem.

Polya (2004) proposes four main stages in problem-solving; understanding the problems, structuring plans for the solutions, implementing the solutions, and reexamining the solutions. Problem-solving skills in mathematics learning are a means for students to develop and examine their ideas, transfer the skill to the uncommon situation, and take charge of their learning development (Das \& Das, 2013). Salido et al. (2020) explain that mathematical problem-solving can provide students with a chance to empower and develop their reflective thinking skills. This research, therefore, is set to Polya's problem-solving stages as it is equipped with a wellstructured framework to solve complex and sophisticated problems, making students more careful in following the steps and procedures for solving the problems.

We integrated Polya's stages with the indicators of reflective thinking (Table 1). In the first stage, students try to understand the given problems by providing an initial response (reaction), for example, state or write what is going to be solved. When planning a solution, they attempt to find the relationship between the questions asked and the available information and then plan a solution. In this case, the students do a comparing activity; compare information from the problem under investigation, reflect on the experience, and then make judgments. At the last two 
stages, they do contemplate activities, reconstructing a situation or problem. Construction activities must precede the reconstruction activities.

\section{Emotional intelligence in learning}

It takes into account intellectual processes aiming for achieving certain goals. Upon their learning, students deal with the thinking process and emotions, especially in solving problems. Consequently, EI appears as an individual awareness of their emotions, and it constitutes an ability to recognize and control emotions and express a sense of sympathy to other people (Reyhani et al., 2012).

People have been granted different emotional intelligence. This difference can be reflected in the students' responses to various problems they face during their learning (Valente et al., 2019). Besides, students' positive emotions will influence their motivation, ways to solve problems, and concentration during their learning. Therefore, emotional intelligence potentially assists students in determining problem-solving strategies.

Goleman (2015) further separates emotional intelligence into five dimensions, i.e., selfawareness, self-management, self-motivation, empathy, and mathematical skill: all of which have aroused our interest in researching the thinking process as a social skill. Moreover, students' emotional intelligence varies with different characteristics. Some differences occur in students' emotional intelligence levels, which are also intertwined with students' reflective thinking skills in solving mathematical problems. In short, the emotional intelligence indicators used in this current research were referred to as emotional intelligence proposed by Goleman.

\section{Methods}

\section{Participants}

This research involved students with different levels of emotional intelligence, which were assessed using a questionnaire developed referring to the indicators by Goleman (2015). Twentynine students with high mathematics ability were given the questionnaire. The students were chosen with the consideration of being able to accomplish the given test following all Polya's stages. This enables us to have rich data regarding their reflective thinking at each stage. The results were 15 students in high levels of emotional intelligence and 14 students in the mid-level. Four students were selected to typify the expected emotional intelligence levels purposively two with high emotional intelligence (S1, S2) and two with middle one (S3, S4). The selection of two students in each category was meant to have a comparison.

\section{Data collection}

In the field, the main instrument of the research was the researchers themselves. To collect the data, a test and interview were administered to the selected students. Specifically, the test was about the Pythagoras theorem, which was supposed to elicit students' reflective thinking. Then, each group of students was interviewed in an unstructured way to confirm her/his answers on the problems and further understand her/his reflective thinking. The test was as follows.

Two poles side by side are $24 \mathrm{~m}$ apart. If the height of the pile is $22 \mathrm{~m}$ and $12 \mathrm{~m}$, respectively, find the length of the connecting wire between the ends of the pile! 
To solve the problem, the students must carry out the reaction, comparison, and contemplation activities. The reaction appears when students state between poles, the height of each pole, and how long the connecting rope is. The comparative activity emerges when comparing the heights of two poles and looking for the differences and formulating the relationship between the difference in the height of the pile and the height of each pile. The contemplate activities are expected when they complete the formulation using the Pythagorean theorems, conclude, and recheck.

\section{Data analysis}

Data analysis follows the procedures of data condensation, data display, and drawing and verifying conclusions (Miles, Huberman \& Saldana, 2014). The raw data were then obtained from the research process by means of tests and interviews. The test results and student interviews were coded deductively according to Table 1 . The data is presented in a narrative and more compact manner as a representative picture of the reflective thinking of all students. The conclusions are drawn by wrapping all research data. In addition, re-testing the suitability of the data collected is also carried out to formulate appropriate conclusions about how students carry out their reflective thinking, especially according to their level of emotional intelligence.

The data reduction referred to Polya's four problem-solving procedures: understanding the problems, structuring plans for solutions, implementing the solutions, and reexamining the solutions: all of which were integrated with the indicators of reflective thinking skill that comprised showing a reaction, making a comparison, and doing contemplation. During reflective thinking, the students made a clear decision for any solution they chose. Henceforth, they needed to reexamine every single step they were through to arrive at the best answer. The indicators of reflective thinking based on Polya's framework are described in the following table.

Table 1. The indicators of reflective thinking for problem-solving

\begin{tabular}{|c|c|c|}
\hline $\begin{array}{l}\text { Polya's stages of } \\
\text { problem-solving }\end{array}$ & $\begin{array}{l}\text { The indicators } \\
\text { of reflective } \\
\text { thinking }\end{array}$ & Descriptions \\
\hline $\begin{array}{l}\text { Understanding the } \\
\text { problem }\end{array}$ & Reaction & $\begin{array}{l}\text { A1 Restating the problem using students' own words } \\
\text { A2 Stating features/elements identified } \\
\text { A3 Stating what is supposed to solve within the } \\
\text { problem }\end{array}$ \\
\hline $\begin{array}{l}\text { Structuring plans } \\
\text { for a solution }\end{array}$ & Comparing & $\begin{array}{l}\text { C1 Explaining a connection between the elements to } \\
\text { find and the ones that have been identified in order } \\
\text { to set up the strategy } \\
\text { C } 2 \text { Making a connection and explain the problem } \\
\text { under investigation by reflecting on experiences } \\
\text { students faced } \\
\text { C3 Probing thoughtful consideration in respect to the } \\
\text { strategy set up and believe that it is effective to solve } \\
\text { the problem }\end{array}$ \\
\hline $\begin{array}{l}\text { Implementing the } \\
\text { solution }\end{array}$ & Contemplating & $\begin{array}{l}\text { T1 Stating the implementation of the strategy clearly } \\
\text { based on the fixed plans } \\
\text { T2 Showing thoughtful consideration in respect to } \\
\text { the steps students take to solve the problem } \\
\text { completely with logical and strong reasons }\end{array}$ \\
\hline
\end{tabular}




\begin{tabular}{lll}
\hline $\begin{array}{l}\text { Polya's stages of } \\
\text { problem-solving }\end{array}$ & $\begin{array}{c}\text { The indicators } \\
\text { of reflective } \\
\text { thinking }\end{array}$ & \multicolumn{1}{c}{ Descriptions } \\
\hline $\begin{array}{l}\text { Reexamining the } \\
\text { solution }\end{array}$ & $\begin{array}{l}\text { Contemplating } \\
\end{array}$ & $\begin{array}{l}\text { P1 Being aware of fallacies at the time of problem- } \\
\text { solving and trying to fix them } \\
\text { P2 Believing in the preciseness of the solution to the } \\
\text { problem investigated }\end{array}$ \\
& $\begin{array}{l}\text { P3 Reexamining the steps to take as well as the } \\
\text { answer } \\
\text { P4 Detecting and fixing up the fallacies committed } \\
\text { P5 Making a good and correct conclusion }\end{array}$ \\
&
\end{tabular}

\section{Findings}

\section{High EI students' reflective thinking}

\section{Understanding the problem}

In this stage, the students showed certain reactions through a specific activity, observing information repeatedly to thoughtfully decide further steps to take and make them at ease in understanding the problem well. Reacting to the given situation could be shown by repeatedly reading the question. It was followed by designing a raw sketch based on the students' understanding, as shown in Figure 1. S1 and S2 sketched the plane as precisely as possible, setting up the size precisely and putting different symbols in both poles. The difference shown by $\mathrm{S} 2$ was reflected from the two parallel lines that denoted the distance of the poles.

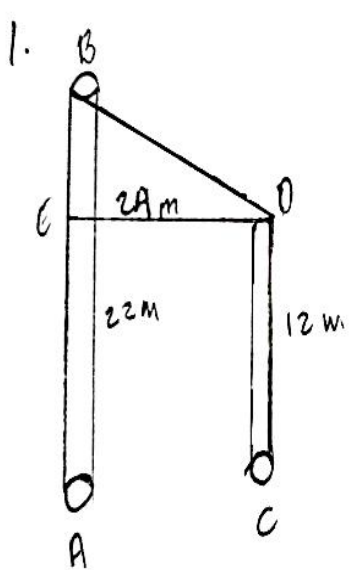

S1's answer
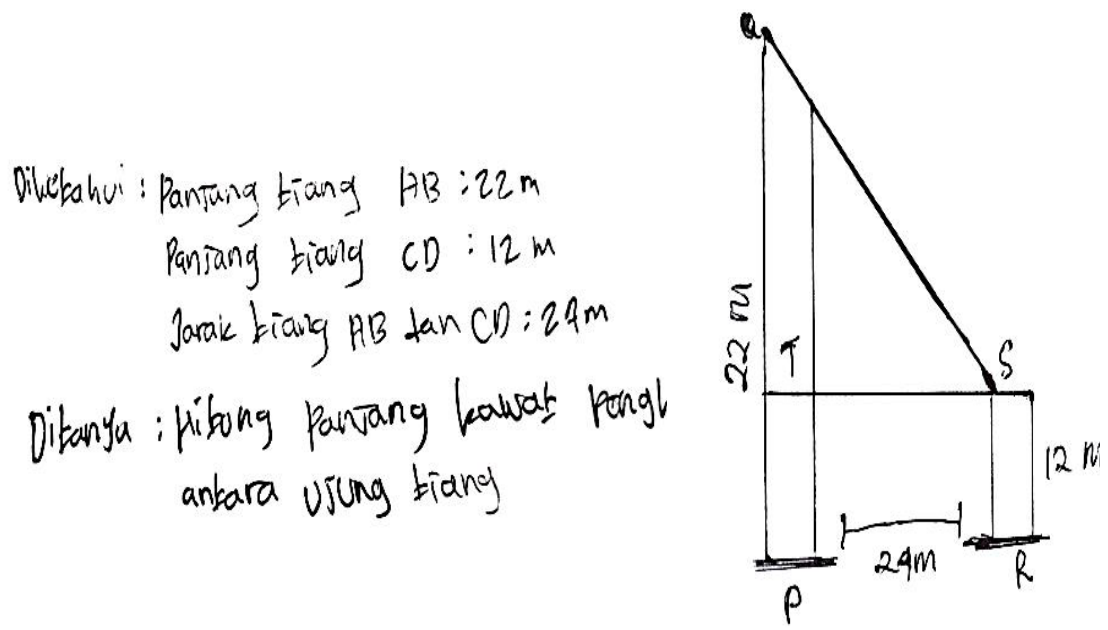

S2's answer

Figure 1. High EI students show reactions in understanding the problem

The students could determine the adequacy of information to solve the given problem. Therefore, in understanding the problem, they could make a connection on the necessary information stated in the problem, which met one of the reflective thinking indicators, showing a reaction. When doing this, they detected adequate information about features to find and the others that had been clearly known so as to make them at ease when designing a strategy. By such a process, they appeared to have met some indicators of reflective thinking, namely: (a) restating the problem using their own words; (b) stating features that had been identified; and 
(c) stating what is supposed to solve within the problem. This was supported by the following excerpt of the interview.

\section{Transcript 1}

$P \quad: \quad$ So, what is the main problem?

S1 : There is a wire connecting Pole 1 and 2. I am supposed to find the length of

the wire (while pointing out the illustration)

$P \quad$ : Could you please tell me about the figure?

So, it is known that Pole 1 is 22 meters long, and Pole 2 is 12 meters. meters.

\section{Structuring plans for the solution}

In this stage, both S1 and S2 were able to draw upon possible solutions in answering the question according to their prior knowledge. It caused diverse patterns of understanding that referred to the illustrations they created. The students were in trouble applying the most appropriate method for the problem given, and thus it took a long time to get into the last step of solving the problem. They then compared by connecting any interrelatedness from the information identified within the figure based on their prior knowledge, e.g., about trapezium, rectangle, and Pythagoras theorem. By doing so, they could shortlist the best solution amidst possibilities.
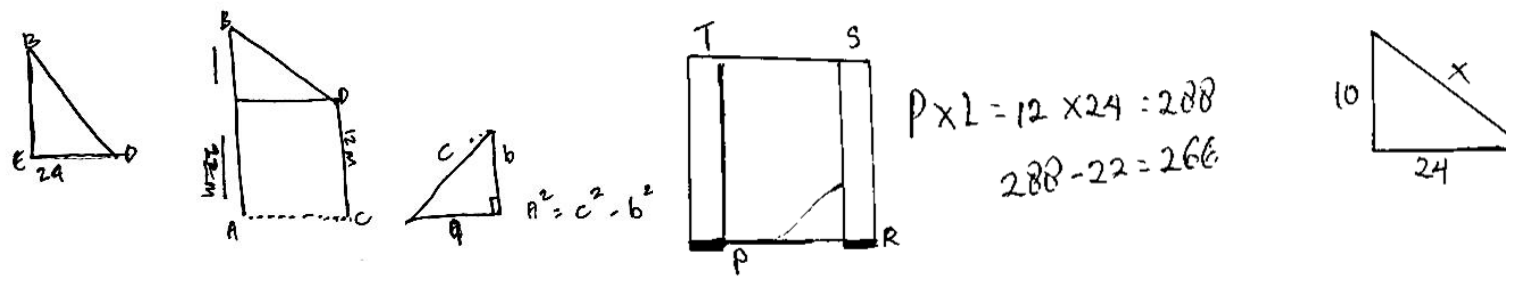

$$
\begin{aligned}
& \text { Parjany } E B \text { ? } \\
& \begin{aligned}
\text { Panjong tiang } A B \text {-tiang CD } \\
=22 \mathrm{~m}-12 \mathrm{~m} \\
=10 \mathrm{~m}
\end{aligned}
\end{aligned}
$$

\section{S1's answer}

Jawab:

Panjang garis $T_{Q}=P_{Q}-$ Panjang garis $T P=R S$ $=22 m-12 m$

$=10 \mathrm{~m}$

Mencan' nilai $x$

Figure 2. High EI students do a comparing activity

The students made use of the prior knowledge by shortlisting possible solutions they formulated. The abovementioned description indicated that to structure the solution, the students could understand well how the question was supposed to be answered so that the whole indicators of reflective thinking could be achieved satisfactorily, such as (a) explaining the connection between features to find and the ones that had been identified in order to structure the strategy; (b) connecting to prior experiences while explaining the problem based on their experiences, and (c) giving a strong reason for every step taken out and believing that the solution 
offered was effective for the problem. It was indicated through the following excerpt of the interview.

\section{Transcript 2}

$P \quad: \quad$ Please tell me in brief about the figure that you created.

S1 : This is a trapezium since the upper part typifies a right triangle. And we

need to find the hypotenuse of the triangle.

S2 : It is because the lower part (pointing to the figure) typifies a rectangle, while the upper part is a right triangle.

\section{Implementing the solution}

Both students were contemplating by giving attention to the previous stages, showing reactions, and comparing. They also could write and explain correctly how to implement the solution, step by step. In addition, they admitted that they had previously dealt with a seemingly similar problem. In this stage, the subjects applied two ways as the solutions. Firstly, they sought the length of one side that remained unknown. Then, they connected it to the application of the Pythagoras theorem as shown by S1, who stated that by knowing the length of EB, the length of the wire could be calculated through $\sqrt{D E^{2}-B E^{2}}$.

$$
\begin{aligned}
& \text { Menean' nilai } x \\
& =\sqrt{Q T^{2}+S T^{2}} \\
& =\sqrt{10^{2}+24^{2}} \\
& =\sqrt{100+576} \\
& =\sqrt{676} \\
& =26 \\
& \text { Jadi, Ranjang dari } Q R=\sqrt{676}=26 \mathrm{~m}
\end{aligned}
$$

Figure 3. High EI students contemplate when implementing the solution (Both students have similar answers)

The aforementioned elaboration denoted that the subjects had performed contemplating in solving the problem, which means that they could explain the whole steps to solve the problem in detail. In the process, the subjects could: (a) state the steps of implementing the strategy as planned; (b) make a thoughtful consideration for any steps to take, and (c) not commit any fallacy in the process of solving the problem, so they had the same answer. These findings were supported by the excerpt of the interview as follows:

\section{Transcript 3}

$P \quad: \quad$ Why did you apply the subtraction on $A B$ and $C D$ ?

$S 1$ : The figure here is like a right triangle EBD, so we need to focus on the little part of $A B$, which is $E B$.

$P \quad: \quad$ Did you ever work on the same problem before? If so, please tell me.

S1 : I think I did, but the problem was straightforward about a right triangle. I was supposed to find the length of the baseline using Pythagoras concept, 


$$
\begin{aligned}
& a^{2}=\sqrt{c^{2}+b^{2}} \\
& P \quad: \quad \text { Then, how will you solve this sort of problem? } \\
& S 2 \quad \text { It is known that } T Q \text { is } 10 \text { meters, so to find the hypotenuse, we need to use } \\
& \text { the concept of } Q R^{2}=\sqrt{Q T^{2}+S T^{2}}=\sqrt{10^{2}+24^{2}}=\sqrt{100+576}= \\
& \sqrt{676}
\end{aligned}
$$

\section{Reexamining the solution}

In this stage, the students believed in the preciseness of the solution. To their understanding, each of the features necessary to solve the problem had been deemed appropriate. They added up that no fallacy was committed during the process of solving the problem. Subsequently, they were confident that they could formulate the right conclusions, as reflected in the following excerpt of the interview.

\section{Transcript 4}

$P \quad: \quad$ So, what is the conclusion?

$S 1$ : Since the wire that connects the poles remains unknown, DB subsists as

$S 2$ : I the wire and signifies 26 meters.

The subjects did contemplation as they believed in the preciseness of their answers and evaluated them according to the sense of appropriateness depicted in the figure. In short, the process had met the indicators of reflective thinking, namely: being aware that no fallacy was committed while solving the problem, believing in the preciseness of the solution, reexamining the steps and the answer obtained, detecting and fixing up fallacies, and drawing a good and correct conclusion.

\section{Mid-level EI students' reflective thinking}

\section{Understanding the problem}

In this stage, the students could identify facts that subsisted in the problem satisfactorily. To help them understand the problem, they created an illustration similar to the previous subjects, as shown in Figure 4. Unlike those with high emotional intelligence levels, S3 did not jot down any symbol representing different poles despite being able to explain everything correctly. The following excerpt of the interview describes the condition.

\section{Transcript 5}

$P \quad: \quad C o u l d y o u$ please tell me the main point of the problem?

S3 : The first pole is 22 meters long, and the second is 12 meters.

$P \quad: \quad$ What is the main problem there?

S3 : We are supposed to find the length of the connecting wire.

$P \quad: \quad$ Is the known feature sufficient enough to solve the problem?

$S 3$ : The distance between the poles is 24 meters long. 


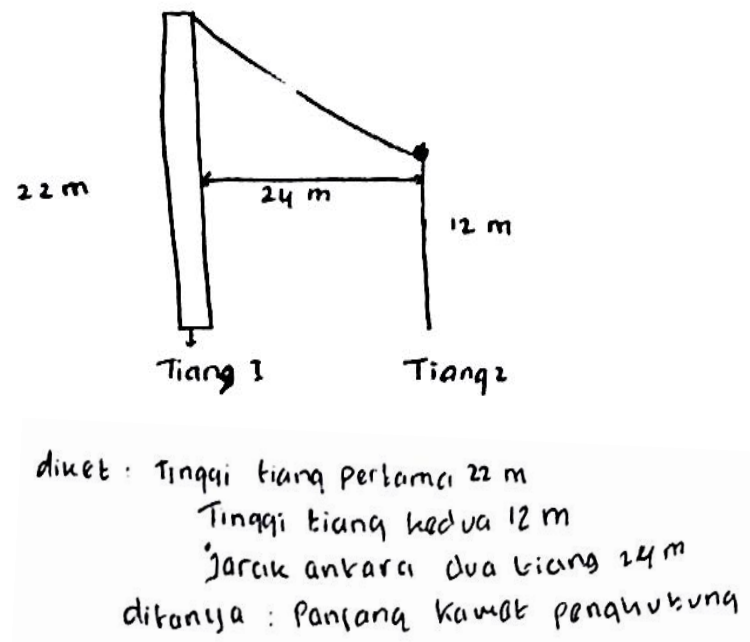

S3's answer
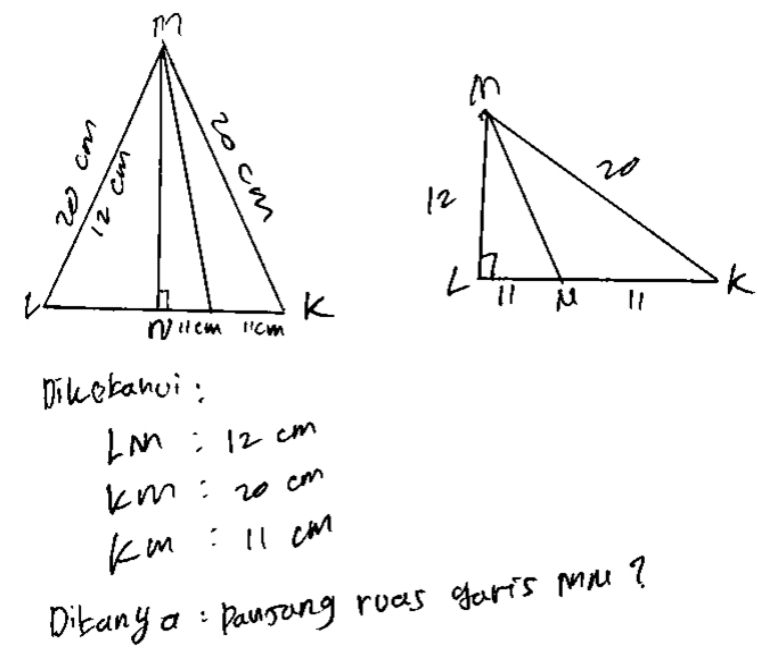

S4's answer

Figure 4. Mid-level EI students show a reaction in understanding the problem

In this case, S4 did not read the question carefully so that mistakes were potential to be committed to illustrating the problem depicted through the figure. Nonetheless, the subject was aware of the mistakes and fixed them up immediately. This was in line with the reaction shown by S4 upon the given situation. It is illustrated in the excerpt of the interview below.

Transcript 6

$P \quad: \quad$ Please tell me in brief what you have known about the figure.

S3 . $K M=20$ centimeters long, $K N=11$ centimeters long, $L M=$

S3 : 12 centimeters long. The $N$ point is located at the KL line.

$P \quad: \quad$ What is the main problem?

$S 3 \quad$ : It is finding the length of MN.

Referring to the facts above, it can be summed up that the students had met the indicators of reflective thinking shown by how they reacted to the problem, including (a) reexplaining/restating the problem using their own words; (b) stating features to find and the ones that had been known in the problem, and (c) stating necessary features to solve the problem.

\section{Structuring plans for the solution}

In this stage, the students exhibited a connection between necessary information in the figure by proposing some problem-solving steps. However, they did not really use their prior knowledge to point up their diverse understanding of the illustrative figures they created. Since the wire that connected the pole was the problem, S3 assumed that the wire was the hypotenuse. Afterward, the student recalled prior experiences in solving a similar problem, which led the subject to use the Pythagoras theorem to arrive at the answer.

\section{Transcript 7}

$P \quad: \quad$ Did you ever work on a similar case?

S3 : I did, but the problem was on each of the sides. Referring to this figure, the problem is not on the hypotenuse but the length of $P R$. 

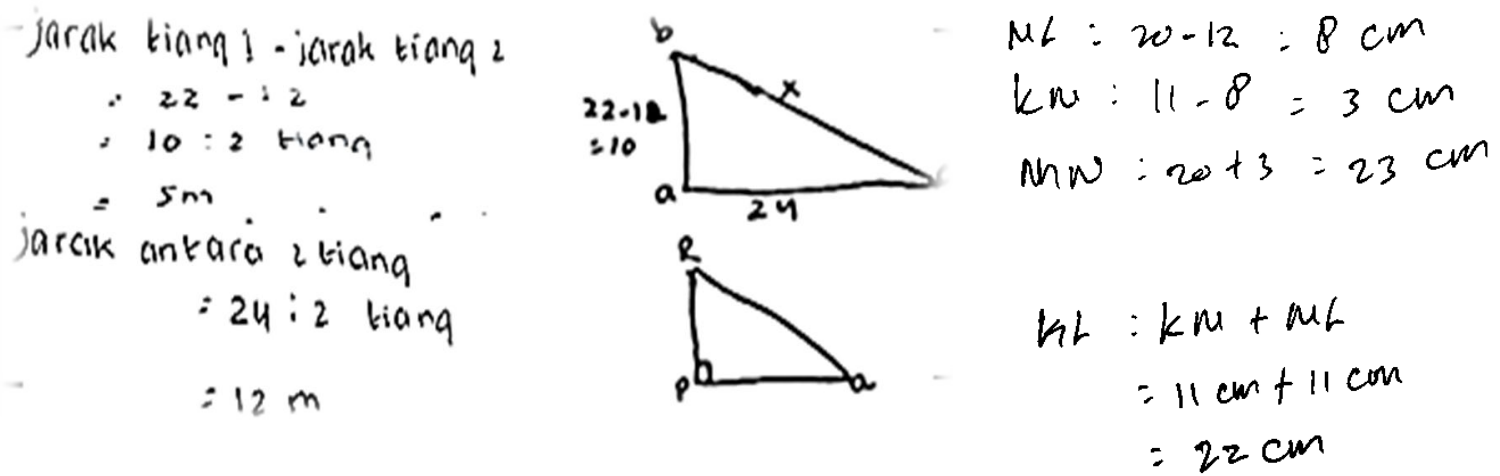

Figure 5. Mid-level EI students contemplate when implementing the solution (both students have similar answers)

Akin to S3, S4 also attempted to formulate some possible alternatives to find the length of the line through the following connection " $N L=M K-L M, K N=K N-N L$, and $M N=$ $M K+K N . "$ In this phase, the subject was aware that a fallacy occurred, especially in the application of the mathematical model. After contemplating, the subject proposed another alternative which was related to the concept of Pythagoras. In this stage, both of the students considered the solution they proposed based on their basic understanding as follows.

\section{Transcript 8}

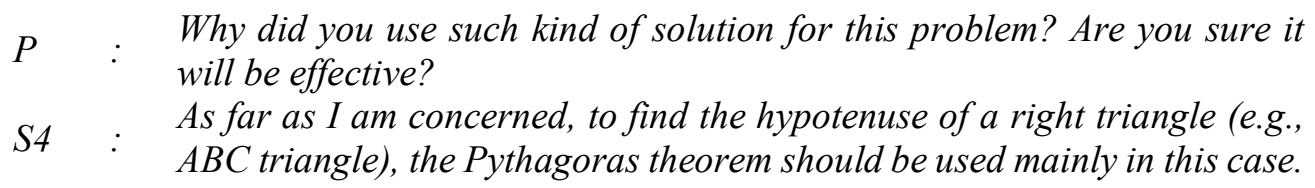

According to the students' answers and interview results, it was found that in this stage, both students had attempted to perform comparing procedure, but unfortunately, the solutions remained incomplete. In other words, it could be concluded that the subjects went through comparing procedures in structuring plans for the solution. However, some indicators of reflective thinking were left incomplete, which was on point $(c)$ - not making any thoughtful and clear consideration on the selected solution and not making a clear and complete connection from the existing information. There remained a different understanding between those with high emotional intelligence levels and those with the average one, specifically in choosing some alternative ways and the number of fallacies committed.

\section{Implementing the solution}

The students proposed the strategy according to their plans in the first and second stages. All procedures they did were interrelated. In this stage, furthermore, they stated that the strategy had been parallel with their formerly structured plans. Nevertheless, according to the result of the interview, the students could not re-explain every single step they did to solve the problem. They even could not utter any good and strong reason for the solution they took. Even though they were given stimuli, fallacies still existed during the process of answering the question. Unfortunately, they remained unaware of the fallacies so as to make them remain mistaken. For 
that reason, the subjects attempted to do contemplating, but they only met one of the indicators. This finding was indicated in the following excerpt of the interview.

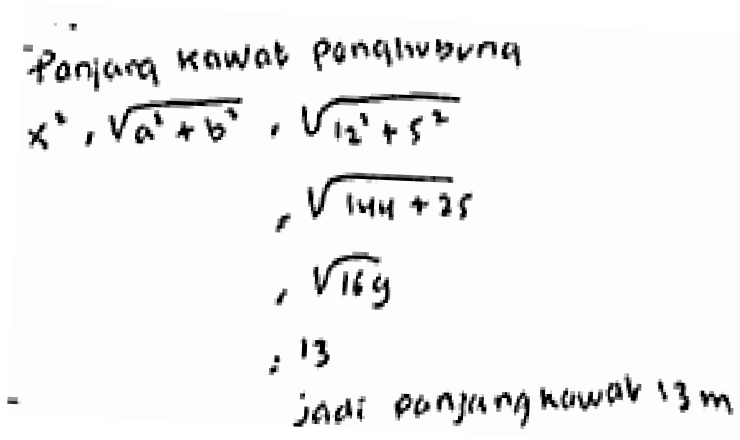

S3's answer

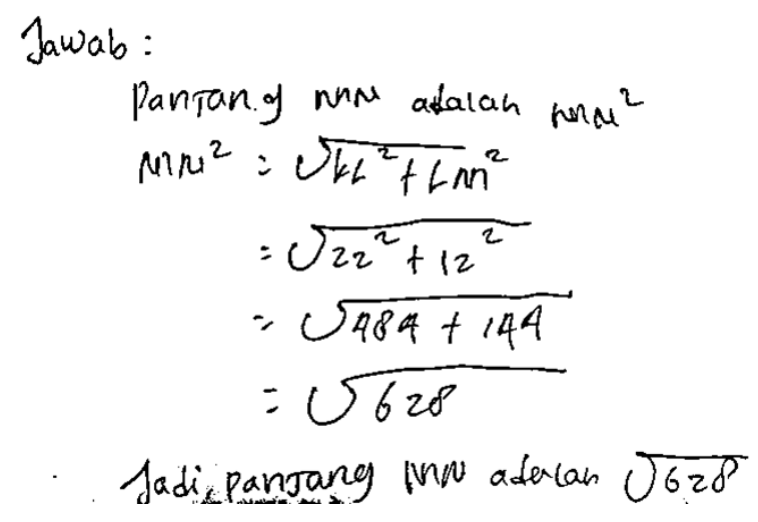

S4's answer

Figure 6. Mid-level EI students contemplated when implementing the solution

\section{Transcript 9}

$P \quad: \quad H o w$ will you apply the Pythagoras theorem to solve the problem?

S3 : We just need to insert $a=12 \mathrm{~m}$ and $b=5 \mathrm{~m}$ into the formula. So, it will be $c^{2}=\sqrt{12^{2}+5^{2}}=\sqrt{144+25=\sqrt{169}}$. The answer is $13 \mathrm{~m}$.

$Q \quad$ : Have you rechecked your steps carefully? Perhaps you missed some.

S4 : Beats me. I am not sure, Ma'am.

\section{Reexamining the solution}

The students had tried to reexamine the illustrations they created but could not detect fallacies in their understanding of the figure. They seemed to have no idea about that but were less motivated to fix up the committed errors. For that reason, they could not make a good and correct conclusion, which made the answer unsuitable with the current information. Such a finding was denoted in the following excerpt of the interview:

\section{Transcript 10}

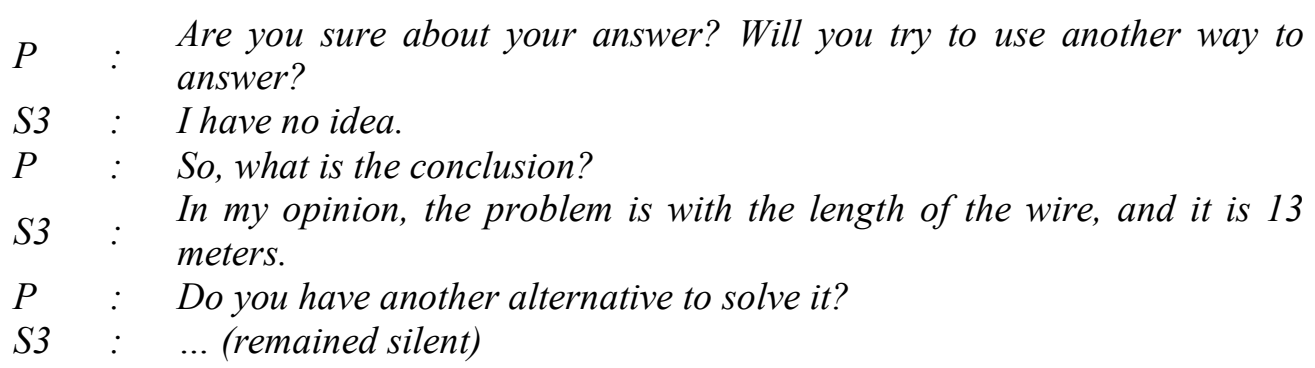

Concerning the abovementioned excerpt of the interview, it could be summarized that in this stage, the students had performed contemplating stage. However, it only covered one of several indicators stipulated, which was to reexamine steps taken out and answers obtained without doing any correction on the existing errors. 


\section{Discussions}

Table 2 depicts students' reflective thinking based on their emotional intelligence in solving mathematics problems. In structuring the solution, the patterns of the high EI students' answers still indicated some difficulties in understanding the existing illustrations, but they kept trying to get the best solutions. In addition, they were also found to do comparing by providing diverse understandings on the illustrations based on the core situation under the focus. They analyzed a possible connection amongst facts depicted in the figure and related them to various relevant problems so that the interconnectedness that was identified could be the basis to solve the problem. MacCann et al. (2020) assert that those with high emotional intelligence levels could analyze any information that has been known and unknown by referring to certain background concepts they have learned. In implementing the solution, the students contemplated every step they did while solving the problem. It was carried out by thoughtful, clear, and consecutive consideration. They were led to making a connection over stages and steps to finish the solution as a result of considerate and careful decisions. This finding supports prior results (Harris et al., 2013) that students with high emotional intelligence levels are equipped with creativity to solve problems. In reexamining, those with high emotional intelligence levels had diverse characteristics in evaluating the process of problem-solving and believing in the preciseness of the answers they generated. For example, the students conduct a contemplation to detect errors in answers, evaluate the suitability of answers with pictures and believe in the truth of answers. Regarding this, Goleman (2015) asserts that emotional intelligence can raise the sense of selfmotivation to carry over self-assessment more accurately so that the whole indicators of reflective thinking can be satisfactorily achieved.

Table 2. A comparison of students' reflective thinking based on emotional intelligence

\begin{tabular}{|c|c|c|}
\hline $\begin{array}{l}\text { Reflective } \\
\text { thinking }\end{array}$ & High level of emotional intelligence & Mid-level of emotional intelligence \\
\hline Reaction & $\begin{array}{l}\text { The students are able to: } \\
\checkmark \quad \text { Explain the problems situation in their } \\
\text { own words } \\
\checkmark \text { Explain the characteristics of the } \\
\text { identified information } \\
\checkmark \text { Explaining what to solve }\end{array}$ & $\begin{array}{l}\text { The students are able to do as the high- } \\
\text { level students do }\end{array}$ \\
\hline Comparisons & $\begin{array}{l}\text { The students are able to: } \\
\checkmark \quad \text { Make connections between elements } \\
\text { to formulate strategies } \\
\checkmark \quad \text { Provide reasons why the strategy was } \\
\text { used }\end{array}$ & $\begin{array}{l}\text { The students are not able to: } \\
\text { - Make connections between elements } \\
\text { to formulate strategies } \\
\text { - Provide reasons why the strategy } \\
\text { was used }\end{array}$ \\
\hline Contemplation & $\begin{array}{ll}\text { The students are able to: } \\
\checkmark \quad \text { Implement the strategies according to } \\
\text { the plans } \\
\checkmark \quad \text { Ensure the accuracy in the problem- } \\
\checkmark \text { solving process } \\
\checkmark \text { Conduct checks to detect errors } \\
\checkmark & \text { Believe the answer is correct }\end{array}$ & $\begin{array}{l}\text { The students: } \\
\text { - Carry out the strategies according to } \\
\text { plan but cannot explain why to use } \\
\text { the strategies } \\
\text { - Check the solution but cannot detect } \\
\text { any errors } \\
\text { - Have no motivation to fix the errors }\end{array}$ \\
\hline
\end{tabular}

In understanding the problem, students with mid-level of emotional intelligence level show reactions by initially drawing illustrations based on the given situations, but they tended to 
commit fallacies for they were less careful to understand pieces of information required in the question (problem). In fact, they were aware of it and rechecked the whole hints to fix up the fallacies committed. This is in line with Tyng et al. (2017) that students who care about emotions or feelings must be caring about changes and improvement. In structuring the plans, the students did not really make use of their mathematical knowledge, so that they could not satisfactorily provide diverse perspectives upon the illustrative figures. In general, they were comparing by connecting features that had been identified and the ones under investigation. However, they did it incompletely so as to cause fallacies of understanding to occur. This is also shown by Supriadi et al. (2015) in their research. The students in this level are capable of stating which features have been known and which to seek but with less confidence in declaring that it has been adequate enough to arrive at the final answer.

Furthermore, in implementing the solution, the mid-level EI students showed the tendency to be able to present the process they had planned. This supports what has been found by Smita et al. (2017). The students tried to re-evaluate the process of obtaining the solution from the beginning to the last stage. They realized some mistakes happened during the implementation process, but they did not make any effort to fix them with other possible solutions. As a consequence, they could not make a good and correct conclusion. Chasanah and Rosyidi (2018) also found that such students often feel doubtful in choosing the best strategy amongst many possibilities.

The current research indicates that, in general, students with high emotional intelligence levels would show reaction upon the given situations by carefully understanding the existing information, transforming the situations into illustrative figures, and filling out the precise numbers as necessary as Prafitriyani et al. (2019) found; the students focus more on understanding the problem, self-motivating to keep on moving forward, and being optimistic about overcoming the problem they face. In addition, they can adequately determine the information that is necessary for structuring the strategy, express different information in understanding the problem, and state features that are supposed to be found and the other ones that have been known.

\section{Conclusion}

This study found that students with high EI levels do reflective thinking in each stage of problem-solving. However, mid-level EI students are not able to think reflectively in solving mathematics problems. In understanding the problem, the mid-level students show a reaction. While structuring plans, they are generally comparing but giving incomplete solutions. Additionally, in implementing and reexamining the solution, they contemplate. Despite being aware of their own mistakes, they did not make any efforts to revise them, which results in an incorrect conclusion. This research unravels that the students' reflective thinking based on their emotional intelligence typifies their different characteristics in solving mathematical problems. Indeed, students with high levels of emotional intelligence are reflective in problem-solving, while students with mid-level emotional intelligence are less reflective. This research implies that students' emotional intelligence is critical to support their reflective thinking. 


\section{References}

Albayrak, M., Şimşek, M., \& Yazıcı, N. (2018). The predictive power to mathematical success of belief and reflective thinking for problem solving. Journal of Human Sciences, 15(2), 807-815. Doi: $10.14687 /$ jhs.v15i2.5141

Awai, D., \& Ogori, E. A.-. (2016). Emotional intelligence and self-concept as predictors of students' academic achievement in mathematics. International Journal of Sciences: Basic and Applied Research (IJSBAR), 29(3), 223-231.

Bayuningsih, A. S., Usodo, B., \& Subanti, S. (2017). Analysis of junior high school students' problemsolving ability reviewed from self-regulated learning. International Journal of Science and Applied Science: Conference Series, 2(1), 51-59. Doi: 10.20961/ijsascs.v2i1.16678

Chasanah, A. U., \& Rosyidi, A. H. (2018). Profil pemecahan masalah matematika siswa SMP ditinjau dari tingkat kecerdasan emosi [The profiles of secondary students' problem-solving based on the levels of emotianal intelligence]. MATHEdunesa: Jurnal Ilmiah Pendidikan Matematika, 1(7), 51-56.

Choy, S. C., \& Oo, P. S. (2012). Reflective thinking and teaching practices: A precursor for incorporating critical thinking into the classroom? International Journal of Instruction, 5(1), 167-182.

Das, R., \& Das, G. C. (2013). Math anxiety: The poor problem solving factor in school mathematics. International Journal of Scientific \& Research Publications, 3(4), 1-5.

Demirel, M., Derman, I., \& Karagedik, E. (2015). A study on the relationship between reflective thinking skills towards problem solving and attitudes towards mathematics. Procedia - Social and Behavioral Sciences, 197, 2086-2096. Doi: 10.1016/j.sbspro.2015.07.326

Deringöl, Y. (2019). The relationship between reflective thinking skills and academic success in mathematics in fourth-grade primary school students. IOJET: International Online Journal of Education \& Teaching, 6(3), 613-622.

Erdoğan, F. (2020). The relationship between prospective middle school mathematics teachers' critical thinking skills and reflective thinking skills. Participatory Educational Research, 7(1), 220-241. Doi: 10.17275/per.20.13.7.1

Funny, R. A., Ghofur, M. A., Oktiningrum, W., \& Nuraini, N. L. S. (2019). Reflective thinking skills of engineering students in learning statistics. Journal on Mathematics Education, 10(3), 445-458. Doi: 10.22342/jme.10.3.9446.445-458

Goleman, D. (2015). Emotional intelligence. Gramedia Pustaka Utama.

Harris, D. J., Reiter-Palmon, R., \& Kaufman, J. C. (2013). The effect of emotional intelligence and task type on malevolent creativity. Psychology of Aesthetics, Creativity, and the Arts, 7(3), 237-244. Doi: $10.1037 / \mathrm{a} 0032139$

Hidayat, M. A. (2018). Increased ability of emotional protection and emotional intelligence of mts negeri 2 medan through mathematical approach realistic. International Journal of Scientific \& Technology Research, 7(4), 54-58.

MacCann, C., Jiang, Y., Brown, L. E. R., Double, K. S., Bucich, M., \& Minbashian, A. (2020). Emotional intelligence predicts academic performance: A meta-analysis. Psychological Bulletin, 146(2), 150186. Doi: $10.1037 /$ bul0000219

Miles, M. B., Huberman, A. M., \& Saldana, J. (2014). Qualitative data analysis: A methods sourcebook. Sage.

Mitchell-White, K. (2010). Reflective thinking and emotional intelligence as predictive performance factors in problem-based learning situations. Walden University.

Muin, A., Novianti, L., \& Musyrifah, E. (2018). Analysis of mathematical reflective thinking skills based on learning model and mathematical prior knowledge. Proceedings of the International Conference on Education in Muslim Society (ICEMS 2017), 21-27. Doi: 10.2991/icems-17.2018.5

Rahmi, N., Zubainur, C. M., \& Marwan. (2020). Students' mathematical reflective thinking ability through scaffolding strategies. Journal of Physics: Conference Series, 1460, 1-8. Doi: 10.1088/1742$6596 / 1460 / 1 / 012022$

Novriani, M. R., \& Surya, E. (2017). Analysis of students' difficulties in mathematics problem solving. International Journal of Sciences: Basic and Applied Research (IJSBAR), 33(3), 63-75.

Paguyo-Gumangan, M. J. (2018). Emotional intelligence: Its relationship to mathematics achievement of senior high school. International Journal of Physics \& Mathematics, 3(1), 30- 47.

Pianpeng, T., \& Koraneekij, P. (2016). Development of a model of reflection using video based on GIBBS' cycle in electronic portfolio to enhance level of reflective thinking of teacher students. 
International Journal of Social Science and Humanity, 6(1), 26-31. Doi: 10.7763/IJSSH.2016.V6.612 Polya, G. (2004). How to solve it: a new aspect of mathematical method. Princeton University Press.

Prafitriyani, S., Magfirah, I., Amir, N. F., Irmawati, A., \& Umanailo, M. C. B. (2019). Influence of emotional intelligence on mathematics learning outcomes. International Journal of Scientific \& Technology Research, 8(10), 1490-1494.

Rasyid, M. A., Budiarto, M. T., \& Lukito, A. (2018). Junior high school students' reflective thinking on fraction problem solving: The case of gender differences. Journal of Physics: Conference Series, 947, 012041. Doi: 10.1088/1742-6596/947/1/012041

Reyhani, E., Hamidi, F., \& Kolahdouz, F. (2012). A study on algebraic proof conception of high school second graders. Procedia - Social and Behavioral Sciences, 31, 236-241. Doi: 10.1016/j.sbspro.2011.12.048

Salido, A., \& Dasari, D. (2019). The analysis of students' reflective thinking ability viewed by students' mathematical ability at senior high school. Journal of Physics: Conference Series, 1157, 1-6. Doi: 10.1088/1742-6596/1157/2/022121

Salido, A., Suryadi, D., Dasari, D., \& Muhafidin, I. (2020). Mathematical reflective thinking strategy in problem-solving viewed by cognitive style. Journal of Physics: Conference Series, 1469, 1-8. Doi: 10.1088/1742-6596/1469/1/012150

Seng, N. L., Hanafi, Z., Taslikhan, M., \& Raman, A. (2016). Influence of emotional intelligence on students' academic achievements. International Journal of Humanities and Social Science Research, 2(3), 41-46.

Shafiee, M., Majdi, H., Khoshkhou, M., \& Rajabi, F. (2016). The processing of relationship between emotional intelligence and mathematics scores. International Journal of Innovation and Research in Educational Sciences, 3(1), 36-39.

Smita, A., Jaeng, M., \& Bennu, S. (2017). Profil pemecahan masalah sistem persamaan linier dua variabel siswa sekolah menengah ditinjau dari kecerdasan emosional tinggi [Profiling students' problemsolving on two variables linear equation based on high level of emotional intelligence]. JRPM: Jurnal Riset Pendidikan MIPA, 5(4), 25-32.

Suharna, H., Hairun, Y., Abdullah, I. H., Alhaddad, I., Afandi, A., Ardiana, \& Sari, D. P. (2020). The reflective thinking elementary student in solving problems based on mathematic ability. International Journal of Advanced Science and Technology, 29(6), 3880-3891.

Supriadi, D., Mardiyana, \& Subanti, S. (2015). Analisis proses berpikir siswa dalam memecahkan masalah matematika berdasarkan langkah polya ditinjau dari kecerdasan emosional [Analyzing students' thinking in solving mathematics problems using Polya viewed from emotianal intelligence]. Jurnal Elektronik Pembelajaran Matematika, 3(2), 204-214.

Toraman, Ç., Orakc1, Ş., \& Aktan, O. (2020). Analysis of the relationships between mathematics achievement, reflective thinking of problem solving and metacognitive awareness. International Journal of Progressive Education, 16(2), 72-90. Doi: 10.29329/ijpe.2020.241.6

Tyng, C. M., Amin, H. U., Saad, M. N. M., \& Malik, A. S. (2017). The influences of emotion on learning and memory. Frontiers in Psychology, 8. Doi: 10.3389/fpsyg.2017.01454

Valente, S., Monteiro, A. P., \& Lourenço, A. A. (2019). The relationship between teachers' emotional intelligence and classroom discipline management. Psychology in the Schools, 56(5), 741-750. Doi: $10.1002 /$ pits.22218

Yildirim, T. (2017). An examination on geography teachers' reflective thinking tendencies. International Journal of Higher Education, 6(6), 78-90. Doi: 10.5430/ijhe.v6n6p78

Zahara, N., Hajidin, \& Abidin, Z. (2020). Reflective thinking process students with visual learning style in mathematical problem solving. International Journal of Scientific Research and Management, 8(09), 187-193. Doi: 10.18535/ijsrm/v8i09.m01 